\title{
PENINGKATAN KREATIVITAS SISWA DALAM PEMBELAJARAN MATEMATIKA MELALUI PENDEKATAN OPEN ENDED PROBLEM
}

\author{
Syamsul Ardi \\ Guru Mata Pelajaran Matematika \\ SMA Negeri 2 Pangkajene \\ E-mail: ardisyamsul@gmail.com
}

\begin{abstract}
ABSTRAK
Penelitian ini adalah penelitian tindakan kelas yang bertujuan untuk meningkatkan kreativitas siswa Kelas X SMA Negeri 2 Pangkajene Kab. Pangkep melalui pendekatan open ended problem. Subjek penelitian ini adalah siswa Kelas X Aljabar SMA Negeri 2 dengan jumlah 28 orang, Siklus I dilaksanakan selama 4 kali pertemuan dan siklus II dilaksanakan 3 kali pertemuan. Pengambilan data dilakukan dengan menggunakan lembar observasi untuk mengetahui tingkat kreativitas siswa selama pembelajaran berlangsung, angket kreativitas untuk mengetahui tingkat kreativitas siswa setelah pemberian tindakan, dan tes hasil belajar sebagai data tambahan untuk mengetahui sejauh mana peningkatan hasil belajar siswa. Hasil penelitian menunjukkan bahwa (a) terjadi peningkatan untuk setiap indikator yang diamati, yaitu: fleksibilitas, originalitas, elaboration dan fluency (b) skor rata-rata kreativitas siswa pada siklus siklus I sebesar 72,96,. Pada kategori rendah dan siklus II 87,86 pada kategori sedang (c) nilai rata-rata hasil belajar siswa pada siklus I yaitu 60,35 dari skor ideal 100 sedangkan pada siklus II yaitu 60,91. Dari hasil penelitian ini dapat disimpulkan bahwa dengan diterapkannya pendekatan open ended problem maka kreativitas belajar matematika siswa Kelas X SMAN 2 Pangkajene mengalami peningkatan.
\end{abstract}

Kata Kunci: Kreatifitas, open-ended, hasil belajar

\section{PENDAHULUAN}

Perkembangan kurikulm matematika dari kurikulum berbasis kompetensi ke Kurikulum 2013, membawa beberapa perubahan dalam hal pergeseran materi matematika dan tingkatan berpikir siswa di jenjang pendidikan SMA, Hal ini tentunya turut mempengruhi proses pembelajaran yang dilaksankan dikelas, hal ini menuntut guru untuk lebih tekun dan lebih banyak mempelajari model, strategi atau metode dalam membelajarkan siswa. Salah satu tujuan pembelajaran matematika dalam kurikulum 2013 (K13) adalah mengembangkan krmampuan berpikir siswa baik dari sisi pengetahuan maupun keterampilan. Salah satu wujud dari keterampilan itu adalah kreativitas matematika siswa. Hingga saat ini, kreativitas siswa yang diharapkan mulai dapat berkembang dan mulai menunjukkan hasil yang menggembirakan.

SMA negeri 2 Pangkajene sebagai salah satu sekolah pelaksana K13, pada proses pembelajaran mengharapkan guru untuk menggunakan model atau metode yang sesuai supaya kreatifitas siswa dapat berkembang dalam pembelajaran. Sebagai salah satu guru matematika, dalam proses pembelajaran menemukan fakta bahwa tingkat kreativitas 
siswa masih dalam kategori kurang, sehingga merasa bahwa perlu adanya sedikit inovasi untuk mengembangkan kreatifitas siswa dalam pembelajaran matematika, khususnya dalam penyelesaian masalah matematika.

Rendahnya kreativitas siswa tercermin dari respon atau jawaban siswa yang umumnya masih mentransfer dari apa yang diajarkan oleh guru, padahal setiap orang dilahirkan dengan potensi kreatif yang berbeda-beda. Ada yang memilikinya lebih dari yang lain, namun tidak ada yang tidak kreatif (Hamalik, 2003: 179). Di lingkungan sekolah, perlu diupayakan suatu iklim belajar yang menunjang pendayagunaan kreativitas siswa, sehingga guru diharapkan: 1) bersikap terbuka terhadap minat dan gagasan apapun yang muncul dari siswa, bersikap terbuka bukan berarti selalu menerima, tetapi menghargai gagasan tersebut; 2) memberi waktu dan kesempatan yang luas untuk memikirkan dan mengembangkan gagasan tersebut; 3) memberi sebanyak mungkin kesempatan pada siswa untuk berperan serta dalam mengambil keputusan; 4) menciptakan suasana saling menghargai dan saling menerima baik antar siswa maupun antar guru; 5) bersikap positif terhadap kegagalan siswa dan membantu mereka bangkit dari kegagalan tersebut.

Pengembangan kreatif siswa ini sangat penting, hal ini dapat diamati dari bergesernya peran guru, yang semula guru seringkali mendominasi kelas kini harus lebih banyak memberikan kesempatan kepada siswa untuk mengambil peran lebih aktif dan kreatif. Namun, kreativitas yang diharapkan ini dimungkinkan tumbuh dan berkembang dengan baik pada siswa, jika lingkungan keluarga, masyarakat dan sekolah turut menunjang mereka dalam mengekspresikan kreativitasnya.

Salah satu pendekatan dalam matematika yang dianggap sesuai untuk mengembangkan kreativitas siswa dalam pembelajaran matematika yaitu pendekatan open ended problem. Open ended problem mendorong siswa untuk mengemukakan jawaban yang berbeda-beda dan semua jawaban itu benar. Sehingga siswa tidak hanya berpikir pada satu jawaban akhir yang umumnya merupakan jawaban yang diterangkan oleh gurunya. Open ended problem mengarahkan siswa pada cara berpikir berikutnya.

Penelitian ini adalah penelitian tindakan kelas dengan upaya untuk menerapkan pendekatan open ended problem yang dapat meningkatkan kreativitas siswa dalam pembelajaran matematika. Dengan mengacu pada pertanyaan penelitian yaitu: "Apakah kreativitas siswa kelas X Aljabar SMA Negeri 2 Pangkajene dalam pembelajaran matematika dapat ditingkatkan melalui pendekatan open ended problem?" 
Hipotesis tindakan penelitian ini adalah: "Jika dilakukan tindakan dengan menerapkan pendekatan open ended problem maka kreativitas siswa SMA Negeri 2 Pangkajene dalam pembelajaran matematika dapat meningkat".

\section{METODE PENELITIAN}

\section{A. Jenis Penelitian}

Penelitian ini merupakan jenis penelitian tindakan kelas yang dilaksanakan selama dua siklus. Tindakan yang dilakukan adalah pendekatan open ended problem dalam pembelajaran matematika dalam tahapan-tahapan perencanaan (planning), pelaksanaan tindakan (action), observasi dan evaluasi (observation and evaluation), dan refleksi (reflection).

\section{B. Lokasi dan Subjek Penelitian}

\section{Lokasi penelitian}

Penelitian ini dilaksanakan di SMA Negeri 2 Pangkajene semester ganjil pada tahun $2016 / 2017$

\section{Subjek penelitian}

Subjek penelitian ini adalah siswa kelas X Aljabar SMA Negeri 2 Pangkajene Kabupaten Pangkep.

\section{Variabel dan Desain Penelitian}

\section{Variabel penelitian}

Variabel dalam penelitian ini adalah kreativitas siswa dalam pembelajaran matematika. Kreativitas siswa dalam pembelajaran matematika yang dimaksud dalam penelitian ini adalah kemampuan berpikir divergen yang terkait dengan indikator fleksibilitas, originalitas, elaboration dan fluency.

\section{Desain penelitian}

Penelitian ini adalah penelitian tindakan kelas yang melibatkan hanya satu kelas saja. Dalam proses pengajaran dibagi atas dua bagian yang disebut dengan siklus kegiatan I dan siklus kegiatan II. Pada setiap siklus dilakukan tindakan yaitu melaksanakan proses pengajaran dengan menggunakan pendekatan open ended problem. Hal yang membedakan antara siklus I dan siklus II adalah tindakan pada siklus II merupakan perbaikan-perbaikan atau penyempurnaan terhadap apa yang telah dilakukan pada siklus I.

\section{Faktor yang Diselidiki}

Pada faktor berikut akan dilihat bagaimana kinerja siswa selama proses pembelajaran berlangsung, dengan memperhatikan kemampuan berpikir divergen siswa 
yang meningkat. Hal ini ditunjukkan dengan adanya perubahan yang tampak dari indikator berikut:

1. Fleksibilitas siswa; yakni menggambarkan keragaman ungkapan atau sambutan siswa terhadap suatu stimulus.

2. Originalitas siswa; yakni menunjuk pada tingkat keaslian sejumlah gagasan, jawaban atau pendapat terhadap sesuatu masalah, kejadian, atau gejala.

3. Fluency siswa; yakni menunjuk pada kuantitas output, lebih banyak jawaban berarti lebih kreatif.

4. Elaboration, yaitu menggambarkan kemampuan memperinci suatu masalah.

\section{E. Instrumen Penelitian}

Adapun instrumen yang dilakukan dalam penelitian ini adalah: (1) Angket kreativitas, untuk mengukur kreativitas siswa dalam pembelajaran matematika. (2) Lembar observasi, untuk mengamati proses belajar mengajar selama tindakan diberikan. (3) Tes hasil belajar sebagai data tambahan untuk mengetahui hasil belajar siswa.

\section{F. Teknik Pengumpulan Data}

Teknik pengumpulan data yang digunakan meliputi: (1) Data selama proses pembelajaran matematika berlangsung diperoleh dengan menggunakan lembar observasi.

(2) Data peningkatan kreativitas siswa dalam pembelajaran matematika diperoleh dengan memberikan angket kreativitas kepada siswa. (3) Data hasil belajar yang digunakan sebagai data tambahan diperoleh denga cara memberikan hasil tes belajar.

\section{G. Teknik Analisis Data}

Data yang diperoleh dari penelitian ini selanjutnya diolah dengan menggunakan metode statistika deskriptif. Teknik statistik deskriptif digunakan untuk mendeskripsikan karakteristik responden. Untuk keperluan tersebut digunakan tabel distribusi frekuensi, rata-rata, standar deviasi dan persentase.

\section{Data kreativitas siswa}

Untuk skor skala kreativitas siswa yang bersifat ordinal, telah ditransvormasikan ke skor yang sifatnya slakar dengan menggunakan pembobotan pada masing-masing kategori untuk setiap nomor instrumen instrumen.

Langkah-langkah pembobotan dilakukan dengan menggunakan langkah-langkah yang dikemukakan likert dengan skala $1-5$ sebagai berikut:

Untuk pernyataan positif, nilai 5 jika menjawab sangat setuju, 4 jika setuju, 3 jika raguragu, 2 tidak setuju, dan 1 jika sangat tidak setuju sebaliknya jika pernytaan itu adalah pernyataan negatif. 
Tingkat penguasaan 30 - 53 dikategorikan "Sangat Rendah"

Tingkat penguasaan 54 - 77 dikategorikan "Rendah"

Tingkat penguasaan 78 - 101 dikategorikan "Sedang"

Tingkat penguasaan 102 - 125 dikategorikan "Tinggi"

Tingkat penguasaan 126 - 150 dikategorikan "Sangat Tinggi"

\section{Data hasil belajar}

Pengkategorian skor hasil belajar matematika digunakan kriteria Abdorakhman Ginting (2010) yang dikembangkan dalam lima tingkatan yaitu sebagai berikut:

Tingkat penguasaan $0 \%-34 \%$ dikategorikan "Sangat Rendah"

Tingkat penguasaan $35 \%-54 \%$ dikategorikan "Rendah"

Tingkat penguasaan $55 \%-64 \%$ dikategorikan "Sedang"

Tingkat penguasaan $65 \%-84 \%$ dikategorikan "Tinggi"

Tingkat penguasaan $85 \%-100 \%$ dikategorikan "Sangat Tinggi"

\section{HASIL PENELITIAN DAN PEMBAHASAN}

\section{A. Hasil Penelitian}

\section{Siklus I}

Pada siklus I siswa diberikan tes kreativitas yang berbentuk kuesioner. Hasil analisis deskriptif skor kreativitas siswa Kelas X Aljabar SMA Negeri 2 Pangkajene dalam pembelajaran matematika dapat dilihat pada Tabel 1 berikut:

Tabel 1. Statistik Skor Kreativitas Belajar Matematika pada Siklus I

\begin{tabular}{lr}
\hline \multicolumn{1}{c}{ Statistik } & SIKLUS I \\
\hline $\mathrm{N}$ & 28 \\
Mean & 72.96 \\
Median & 74.00 \\
Mode & 74 \\
Std. Deviation & 2.301 \\
Range & 10 \\
Minimum & 67 \\
Maximum & 77 \\
Sum & 2043 \\
\hline Sumber: Data Primer, Tahun: 2016
\end{tabular}

Berdasarkan Tabel 4.1 dapat dikemukakan bahwa skor rata-rata kreativitas siswa dalam pembelajaran matematika yang dicapai responden adalah 72,96 dari skr ideal yang dicapai 150 dengan standar deviasi 2,301. Ini menunjukkan bahwa secara keseluruhan siswa Kelas X Aljabar SMA Negeri 2 Pangkajene yang dijadikan subjek penelitian, 
memiliki kreativitas dalam pembelajaran matematika sekitar $48,64 \%$ dari kreativitas ideal yang harus dimiliki. Perolehan skor kreativitas untuk siklus I adalah 77 untuk skor tertinggi dan 67 untuk skor terendah. Setelah skor responden dikelompokkan dalam 5 kelompok (kelas) dengan mengacu pada pengelompokan yang dikemukakan pada gambar diatas, maka hasilnya dapat dilihat pada Tabel berikut ini.

Tabel 2. Distribusi Skor Kreativitas Belajar Matematika Pada Siklus I

\begin{tabular}{cccc}
\hline Interval (Dalam Skor) & Frekuensi & Kategori & Persentase \\
\hline $30-53$ & 0 & Kreativitas Sangat rendah & $0 \%$ \\
$54-77$ & 28 & Kreativitas Rendah & $100 \%$ \\
$78-101$ & 0 & Kreativitas Sedang & $0 \%$ \\
$102-125$ & 0 & Kreativitas Tinggi & $0 \%$ \\
$126-150$ & 0 & Kreativitas Sangat Tinggi & $0 \%$ \\
\hline
\end{tabular}

Sumber: Data Primer, Tahun: 2016

Berdasarkan Tabel 2 dapat dikemukakan bahwa dari 28 siswa Kelas X Aljabar SMA Negeri 2 Pangkajene terdapat $100 \%$ yang tingkat kreativitasnya berada pada kategori rendah. Jika skor rata-rata siswa pada siklus I yaitu 72,96 dikelompokkan pada kategori diatas, maka tingkat kreativitasnya tergolong rendah.

\section{Siklus II}

Pada siklus II siswa diberikan tes kreativitas yang berbentuk kuesioner. Hasil analisis deskriptif skor kreativitas siswa Kelas X SMA Negeri 2 Pangkajene dalam pembelajaran matematika dapat dilihat pada Tabel 3 berikut:

Tabel 3. Statistik Skor Kreativitas Belajar Matematika pada Siklus II

\begin{tabular}{lr}
\hline \multicolumn{1}{c}{ Statistik } & \multicolumn{2}{c}{ SIKLUS II } \\
\hline $\mathrm{N}$ & 28 \\
Mean & 87.86 \\
Median & 86.00 \\
Mode & 82 \\
Std. Deviation & 7.644 \\
Range & 30 \\
Minimum & 77 \\
Maximum & 107 \\
Sum & 2460
\end{tabular}

Sumber: Data Primer, Tahun: 2016

Berdasarkan Tabel 4.3 dapat dikemukakan bahwa skor rata-rata kreativitas siswa dalam pembelajaran matematika yang dicapai responden adalah 87,86 dari skor ideal yang dicapai 150 dan standar deviasi 7,64. Ini menunjukkan bahwa secara keseluruhan 
siswa Kelas X SMAN 2 Pangkajene yang dijadikan subjek penelitian, memiliki kreativitas dalam pembelajaran matematika sekitar $58,57 \%$ dari kreativitas ideal yang harus dimiliki. Perolehan skor kreativitas untuk siklus II adalah 107 untuk skor tertinggi dan 77 untuk skor terendah.

Setelah skor responden dikelompokkan dalam 5 kelompok (kelas) dengan mengacu pada pengelompokan yang dikemukakan pada gambar diatas, maka hasilnya dapat disajikan pada Tabel berikut ini.

Tabel 4. Distribusi Skor Kreativitas Belajar Matematika Pada Siklus II

\begin{tabular}{cccc}
\hline Interval (Dalam Skor) & Frekuensi & Kategori & Persentase \\
\hline $30-53$ & 0 & Kreativitas Sangat rendah & $0 \%$ \\
$54-77$ & 1 & Kreativitas Rendah & $3,57 \%$ \\
$78-101$ & 25 & Kreativitas Sedang & $89,29 \%$ \\
$102-125$ & 2 & Kreativitas Tinggi & $7,14 \%$ \\
$126-150$ & 0 & Kreativitas Sangat Tinggi & $0 \%$ \\
\hline
\end{tabular}

Sumber: Data Primer, Tahun: 2016

Berdasarkan Tabel 4 dapat dikemukakan bahwa dari 28 siswa Kelas X Aljabar SMA Negeri 2 Pangkajene terdapat 89,29 yang tingkat kreativitasnya berada pada kategori sedang, dan 7,14\% kreativitas siswa berada pada kategori tingg dan 3,57\% berada pada kategori rendah. Jika skor rata-rata siswa pada siklus II yaitu 87,86 dikelompokkan pada kategori di atas, maka tingkat kreativitasnya tergolong sedang.

Berdasarkan Tabel 4 dan tabel 2 diatas dapat dikemukakan bahwa adanya peningkatan kreativitas belajar matematika siswa setelah diadakan dua kali tes siklus. Jumlah siswa dengan kreativitas yang berada dalam kategori rendah terjadi penurunan yaitu pada siklus I terdapat2 siswa (100\%) sedangkan pada siklus II terdapat siswa $(3,57 \%)$ yang berada pada kategori rendah, sedangkan yang berada pada kategori sedang pada siklus I tidak ada, maka pada siklus II menjadi 25 siswa $(89,29 \%)$.

Dari Tabel 4 juga dapat dilihat untuk tingkat kreativitas yang berada pada kategori tinggi mengalami peningkatan, pada siklus I tidak terdapat siswa (0\%), sedangkan pada siklus II terdapat 2 siswa $(7,14 \%)$. Hal ini menunjukkan bahwa telah terjadi peningkatan kreativitas siswa Kelas X Aljabar SMA Negeri 2 Pangkajene dalam pembelajaran matematika melalui pendekatan open ended problem. 


\section{B. Pembahasan}

Selain meningkatnya kreativitas siswa dalam pembelajaran matematika, dalam penelitian ini juga terjadi peningkatan hasil belajar matematika yang diperoleh dari hasil tes hasil belajar siswa di setiap akhir siklus.

Analisis deskriptif skor hasil belajar matematika siswa Kelas X Aljabar SMA Negeri 2 Pangkajene setelah diberikan tes siklus I dan Siklus II disajikan pada Tabel 5 berikut:

Tabel 5. Deskripsi Skor Hasil Belajar Matematika pada Siklus I dan Siklus II

\begin{tabular}{ccc}
\hline \multirow{2}{*}{ Statistik } & \multicolumn{2}{c}{ Nilai } \\
\cline { 2 - 3 } & Sikluis I & Siklus II \\
\hline Skor Ideal & 100 & 100 \\
Rata-Rata & 60,35 & 60,91 \\
Standar Deviasi & 1,29 & 1,42 \\
Median & 60,75 & 70,08 \\
Skor Maximum & 80,50 & 90,50 \\
Skor Minimum & 40,50 & 40,75 \\
\hline
\end{tabular}

Sumber: Data Primer, Tahun: 2016

Dari Tabel 5 di atas terlihat peningkatan skor rata-rata hasil belajar siswa dari siklus I ke siklus II . Pada siklus I skor rata-rata hasil belajar siswa Kelas X Aljabar SMA Negeri 2 Pangkajene adalah 60,35 dengan standar deviasi 1,29, sedangkan pada siklus II skor rata-rata hasil belajar siswa Kelas X Aljabar SMA Negeri 2 Pangkajene adalah 60,91 dengan standar deviasi 1,42.

Pada Tabel 4.7 di bawah ini memperlihatkan distribusi frekuensi dan persentase hasil belajar siswa setelah dilaksanakan pembelajaran dengan pendekatan open ended problem pada siklus I dan Siklus II.

Tabel 6. Distribusi Frekuensi dan Persentase Skor Hasil Belajar Matematika Siswa Pada Siklus I dan Siklus II

\begin{tabular}{|c|c|c|c|c|c|}
\hline \multirow[b]{2}{*}{ Nilai } & \multirow[b]{2}{*}{ Kategori } & \multicolumn{2}{|c|}{ Frekuensi } & \multicolumn{2}{|c|}{ Persentase } \\
\hline & & $\begin{array}{c}\text { Siklus } \\
\text { I }\end{array}$ & $\begin{array}{c}\text { Siklus } \\
\text { II }\end{array}$ & $\begin{array}{c}\text { Siklus } \\
\text { I }\end{array}$ & $\begin{array}{c}\text { Siklus } \\
\text { II }\end{array}$ \\
\hline $0,0-30,4$ & Sangat Kurang & 0 & 0 & $0 \%$ & $0 \%$ \\
\hline $30,5-50,4$ & Kurang & 5 & 4 & $27 \%$ & $22 \%$ \\
\hline $50,5-60,4$ & Sedang & 1 & 1 & $6 \%$ & $6 \%$ \\
\hline $60,5-80,4$ & Baik & 11 & 11 & $61 \%$ & $61 \%$ \\
\hline $80,5-100,0$ & Sangat Baik & 1 & 2 & $6 \%$ & $11 \%$ \\
\hline \multicolumn{2}{|c|}{ JUMLAH } & 18 & 18 & $100 \%$ & $100 \%$ \\
\hline
\end{tabular}

Sumber: Data Primer, Tahun: 2016 
Berdasarkan Tabel 6 di atas dapat dilihat adanya peningktan hasil belajar matematika siswa setelah diadakan dua kali tes siklus . Tidak ada siswa yang berada pada kategori penguasaan materi yang sangat kurang pada siklus I dan Siklus II. Pada siklus I terdapat 5 siswa (27\%) yang berada pada kategori kurang, sedangkan pada siklus II menjadi 4 siswa (22\%).

Berdasarkan Tabel 6 juga dapat dilihat untuk penguasaan materi yang berada dalam kategori sedang jumlahnya tetap, baik pada siklus I dan siklus II yaitu 1 siswa (6\%). Untuk tingkat penguasaan materi yang berada pada kategori baik, pada siklus I dan siklus II tetap sama, yaitu 11 siswa (61\%). Untuk tingkat penguasaan materi yang berada pada kategori sangat baik, pada siklus I terdapat 1 siswa $(6 \%)$ sedangkan pada siklus II meningkat menjadi 2 siswa (11\%). Hal ini menunjukkan bahwa telah terjadi peningkatan hasil belajar matematika siswa Kelas X Aljabar SMA Negeri 2 Pangkajene melalui pendekatan open ended problem.

\section{KESIMPULAN DAN SARAN}

\section{A. Kesimpulan}

Berdasarkan hasil penelitian dan pembahasan diperoleh kesimpulan sebagai berikut :

1. Terjadi peningkatan keadaan siswa selama proses belajar mengajar berlangsung, untuk setiap indikator (fleksibilitas, originalitas, fluency, dan elaboration siswa) yang diamati dari siklus I dan siklus II.

2. Kreativitas siswa Kelas X Aljabar SMA Negeri 2 Pangkajene dalam pembelajaran matematika mengalami peningkatan dari siklus I ke siklus II dengan skor rata-rata pada siklus I yaitu 72,86 berada dalam kategori rendah, sedangkan skor rata-rata II adalah 87,86 dari skor ideal 100 berada dalam kategori sedang.

3. Hasil belajar matematika siswa Kelas X X Aljabar SMA Negeri 2 Pangkajene mengalami peningkatan dari siklus I ke siklus II dengan skor rata-rata pada siklus I yaitu 60,35 sedangkan pada siklus II yaitu 60,91 .

\section{B. Saran}

Berdasarkan hasil penelitian dan pembahasan serta kesimpulan yang telah dikemukakan di atas, dapat disarankan sebagai berikut :

1. Perlu adanya penelitian lanjutan mengenai pendekatan open ended problem dalam upaya meningkatkan kreativitas siswa dalam pembelajaran matematika pada tingkat kelas yang berbeda. 
2. Pendekatan open ended problem layak untuk dipertimbangkan menjadi pembelajaran alternatif dalam rangka meningkatkan kreativitas siswa dalam pembelajaran matematika, karena dengan pendekatan ini siswa cenderung lebih kreatif pada proses pembelajaran sehingga dapat belajar lebih maksimal.

\section{DAFTAR PUSTAKA}

Abdorakhman Ginting. 2010. Esesnsi Praktis Belajar dan Pembelajaran. Bandung: Humaniora

Ahmadi. 2002. Psikologi Sosial. Jakarta: Rineka Cipta.

Gea, A. A. 2003. Relasi Dengan Diri Sendiri. Jakarta: Elex Media Komputindo.

Hamalik. O. 2003. Perencanaan Pengajaran berdasarkan Pendekatan Sistem. Bumi Aksara.

Khusnul, K. 2006. Meningkatkan Kreatiivitas Siswa Kelas VII SMP 24 Pangkep. dalam Pendekatan Open Ended Problem. Skripsi Jurusan Matematika Fakultas Matematika dan Ilmu Pengetahuan Alam Universitas Negeri Pangkep.

Poerwadarminta, WJS \&Wojowasito, S. 1980. Kamus Inggris Indonesia. Bandung: Hasta.

Sardiman. 2003. Interaksi dan Motivasi Belajar Mengajar. Jakarta: Raja Grafindo Persada.

Slameto. 2003. Belajar dan Faktor-faktor yang Mempengaruhinya. Jakarta: Raja Grafindo Persada.

Suherman, H. 2003. Strategi Pembelajaran Matematika Kontemporer. Universitas Pendidikan Indonesia: JICA.

Welyati, A. 2005. Efektivitas pendidikan Open Ended dalam Meningkatkan Hasil Belajar Matematika Siswa Kelas X SMAN 8 Pangkep. . Skripsi Jurusan Matematika Fakultas Matematika dan Ilmu Pengetahuan Alam Universitas Negeri Pangkep. . 